\title{
Halal Thayyib \& Kosher Food in Legal Conceptual Framework Based on Social Study in Indonesia and America
}

\author{
*Ikomatussuniah \\ PhD Student of Centre for Policy Research and \\ International Studies, UniversitiSains Malaysia \\ Malaysia \\ iko@untirta.ac.id
}

\begin{abstract}
In Islamic teachings, the terms Halal-Thayyib are often used together in unison. Thayyib brings in the ontology of goodness into the discourse of religious permissibility (Halal). Nevertheless, Thayyib is often being removed from the legal and social dynamics of Halal contextualization. This article aims at examining the extent of existence or marginalization of the Thayyib construct from two different legal environments, namely Indonesia and the Americas of America (USA). Indonesia is chosen because it is the most populated Muslim nation, while the U.S. is the country that has a public regulation on Kosher food laws. Moreover, to signify that a 'product/output' ought to be religiously permitted (Halal) and good (Thayyib), this article has a three-prong objective. Firstly, to compare the criteria of Halal food with Kosher food as defined in Indonesia and the Americas respectively. Secondly, to compare the written laws and regulations that have been instituted in both countries visa-vis Halal \& Kosher food and to identify the overlapping spaces between these two definitions as well as laws and regulations. Lastly, to examine the ontological gaps in the context of Thayyib within Halal and Kosher foods. Document review used as a method in qualitative design. The result says that in specific regulation the Halal Thayyib used as a principal at both of regulations in essence. However, there is some overlapping covenant that might the consumer get confused. Moreover, this study contributes to better policy in Halal Thayyib in regulation forms.
\end{abstract}

Keywords: Halal \&Thayyib, Kosher, Food Laws

\section{INTRODUCTION}

Food is one of the basic human needs in order to fulfill their needs. Food generally defined as anything that can be eaten or consumed orally to the body as an energy source [1]. Furthermore, in America, food can be in the form of food or drinks for humans or other animals [2] regulated in various regulations, such as the Federal Food, Drug, and Cosmetic Act (FD\&C Act), 21 U.S.C section 321 et seq., and The Food and Drug Administration (FDA). In Indonesia, food is regulated in Act No. 18 of 2012. It is defined as everything from biological sources of agricultural products, plantations, forestry, fisheries, livestock, water, and water, both processed and untreated which are intended as food or beverages for human consumption, including food additives, food raw materials. There are special rules related to food in Indonesia, for example, the rules

\author{
Mohammad Reevany bin Bustami \\ Researcher and Assoc. Prof at Centre for Policy \\ Research and International Studies, UniversitiSains Malaysia \\ Malaysia \\ reevany@usm.my
}

regarding Halal Product Guarantees contained in the Act of the Republic of Indonesia Number 33 of 2014.

Al-Halal (the lawful): That which is permitted, concerning which no restriction exists, and the doing of which the Law-Giver, Allâh, has allowed. Al-Haram (the prohibited or unlawful): that which the Law-Giver has prohibited; anyone who engages in it is liable to incur the punishment of Allâh in the Hereafter as well as a legal punishment in this world [3]. Halal Thayyib is the basis of theology in Islam to regulate its people in consuming food and drinks so that life is good and healthy. Thus, it can carry out its activities in worship to God and be able to relate or interact with other creatures without any constraints. Halal food is the law established in the Quran related to food and beverages that consumed legally. Meanwhile, the opposite of Halal law is haram, where it is forbidden to eat or consume because it contains terrible things for the human body and soul. Then, Thayyib is good, healthy and beneficial food for the body. In addition, the material must be Halal food, and provisions Thayyib assured that the food must meet the standards of hygiene, nutrition, health and safety in pre, and post-presentation period, for example, related to the handling, packing, distribution, and storage [4].

Problems arise when food-related regulations do not explain clearly whether or not a product is Halal. By analyzing the situation in various parts of the world, especially the Muslim community, the Islamic concept is unclear and not fully accepted [4]. The public was confused and in doubt, as to consume or buy a food product, so it does not guarantee security and comfort. This condition happens because the definition of Halal Thayyib interpreted differently from one another. In this case, several opinions emerged in the community group regarding the definition or understanding of Halal Thayyib foods. Finally, for certain groups, Halal and Thayyib are not important. Based on these symptoms, it is necessary to review the literature related to regulation to ascertain whether what is meant in the legislation that has been ratified and attempted to run in the country concerned, namely Indonesia and America. Indonesia is a country with a majority Muslim population. Based on the population census of the Central Statistics Agency (BPS) in 2010, there 207,176,162 Indonesian 
citizens were embracing Islam [5]. Muslims everywhere, are subject to the teachings contained in the Holy Qur'an, AlHadith and Sunnah. Regarding food, Halal Thayyib food has ordered and written in the Holy Qur'an. In general, people in Indonesia understand that Halal is a portion of food that does not contain pigs, khamr and must slaughter with Islamic values. However, a phenomenon arises when people consume food without understanding the actual laws. For example, when people consume processed products from chicken, as long as there is a Halal logo, they eat it without examining whether the foods correctly processes or not. If the chicken has been cut using an Islamic method, then when processing added chemicals such as dyes or MSG, which can damage or give a detrimental effect to the human body and mind that consume it, even though Halal is still non Thayyib. Therefore, it should not consume.

America represented as a state which recognizes Kosher food. In the Declaration of Human Rights of the United Nations in 1948, declared that the ethical dimension and human rights related to food security had become a paramount concern now [6]. America adapts the right to exercise faith to be protected, especially about implementing food laws. Ensuring that food is safe to eat, and that dishonest practices do not deceive consumers, have been among the critical tasks entrusted to governments since antiquity. Throughout history, many countries have independently developed food laws and regulations, and have often found different solutions to ensure that food was safe, up to the quality expected and that consumers received sufficient and accurate information about the products they were purchasing. However, the differences between national requirements and specifications often make it difficult to trade food across borders [7].

In public law, America has not adopted the law of Halal Thayyib food. However, in theory, based on the above Kosher food study, it is not possible to give Muslim rights in Halal Thayyib as well as the rights of Jews, especially in America. Therefore, it is deemed necessary to equate perception, what is meant by Halal Thayyib related to food, so that it can become a benchmark in general and not seen as private law.

The problem address in order to criticize the search for literature related to the definition of Halal Thayyib in the literature of the two countries' regulation. Namely, Indonesia and America. First, to compare the criteria of Halal food with Kosher food as defined in Indonesia and the Americas. Second, to compare the written laws and regulations that have instituted in both countries vis-a-vis Halal \& K-food. Next, to identify the overlapping spaces between these two definitions as well as laws and regulations. Finally, to examine the ontological gaps in the context of Thayyib within Halal and Kosher foods.

\section{RESEARCH METHOD}

The methodology used in this study is to use the deductive method with documents review in qualitative design. Literature sources are from books on food regulations and laws, laws about Kosher foods, journals, and the internet.

\section{A. Comparison of Halal Thayyib \& Kosher food in Indonesia and USA}

1) Halal Thayyib Food Laws in Islamic Theology

Food is a basic need for human existence. Food consumed by Muslims to be following the provisions of Islamic food called Halal food (Ambali\&Bakar, 2014). Increasing awareness of Muslims about the obligation to consume Halal Thayyib food makes a great opportunity in the market for Halal food products. Halal food and beverages became the target of all Muslims to be able to carry out the provisions of Islamic laws, which governs human life to live right, healthy and prosperous. Therefore, to protect the integrity of Halal Thayyib in food products, the proper awareness and a better understanding of among other things the parties involved -in the supply of Halal Thayyib food- must be created [8]. Thus, the public gets security guarantees related to food that they purchase and consume.

Islam asks Muslims to consume Halal foods and avoid Haram ones [3]. Islam asks Muslims to consume Halal foods and avoid haram ones [9]. With the increase in the Muslim consumers' knowledge of their religion, they have become more particular of the type of product and services that they consume or use [10]. The Quran has stresses heavily on the consumption of Halal foods through numerous verses. One of them translates as "O mankind, eat from whatever is on earth (that is) lawful and good and do not follow the footstep of satan. Indeed, he is to you a clear enemy" (The Holy Quran 2: 168). In this verse, there are two crucial Arabic words which are the word Halal (حلال) which means allowed, permitted or lawful and the word Thayyib (طي) which means good and pure. The verse indicates that the concept of Halal food also includes aspects of quality, safety, hygiene, and sanitation ensuing in the term 'HalaalanThayibban' which means permissible and proper [11]. In the Quran, the phrase Halal Thayyib, which refers to food and drink, is an inseparable unity. Four verses call for humans to consume food "HalaalanThayyiban," namely in the letter Al-Baqarah verse 168, the letter AlMaidah verse 88, the letter Al-Anfaal verse 69 and the vein of An-Nahl verse 114, they are: Al-Baqarahayat 168; "O mankind, eat from whatever is on earth (that is) lawful and good and do not follow the footstep of satan. Indeed, he is to you a clear enemy".

a. Al-Maidahayat 88; "and eat what Allah has provided for you (which is) lawful and good. And fear Allah, in whom you are believers".

b. Al-Anfaalayat 69: "So consume what you have taken of war booty (as being) lawful and good, and fear Allah. Indeed, Allah is forgiving and merciful." 
c. Al-Nahlayat 114; "Then eat what Allah has provided for you (which is) lawful and good. And be grateful for the favor of Allah, if it is

(indeed) Him that you worship".

These verses explain that Halal food must be food containing HalalanThayyiban. Many Muslims and NonMuslims consumers still do not understand the spirit of Syariah governing to the products. Halal principles are not confined to the strictly religious but involve health, cleanliness, and safety [12]. Thayyib as a quality standard for goods or products. Good and pure foods are divided into two categories; good and pure in quality good and pure because it is Halal [12]. In Islam, there is no prohibition on processing food as long as the food processing facility is free from Haram and healthy, safe and good quality foodingredients [13]. By definition, Halal consists of everything that is free of components or ingredients that prohibit for consumption by Muslims[14]. In this case, the state must take a role in implementing Syariah laws, so that people get good food. Moreover, food safety and health are guaranteed.

\section{2) American Food Law and Kosher}

Laws in the Americas are divided on Private Law and Public Law. Private law deals with disputes between individuals, businesses, or other organizations. On the other hand, public law relates to the relationship between the government and its citizens [15]. The book states that as time passes, food law created. Samarian tribe does have rules require that employers provide their customers an excellent quality beer or hands will be cut. In the Gospels, there are many references to food and food law. In general, this law revealed to Moses, and this is the basis of Kosher food law for Jews. This law also contains animals that are clean and unclean and which are forbidden to be consumed in practice. They also explained using a good scale in the market [15]. Kosher in Biblical Hebrew means "fit." In the beginning, this term was only for the slaughter of animals, but now includes all food for those who comply with Jewish food laws. Moreover, non-Kosher is unclean food, and this refers to as "treif." [16].The reason for the establishment of food law is to ensure consumers get the food they pay for, providing that food is safe, and to implement religious beliefs. Adulterate is to corrupt, debase, or make impure by the addition of a foreign or inferior substance or element; especially: to prepare for sale by replacing more valuable with less valuable or inert ingredients [17].

Based on the book Guide to Food Laws andRegulation [15], it described that American FoodLaws started from the local community that based on England's rules. In 1641, The Massachusetts Bay Colony published the first food adulteration law in protecting meat and pork, and in 1646, the first colonial Assize of Breads enacted. However, adulteration later became a big problem. Coupled with the development of food technology that makes more and more food substances added to food processing. Therefore, in 1880 , the enactment of a national food and drug laws was recommended. For more details, the development of food laws in America can be seen in Table 1.

TABLE I.

AMERICAN FOOD LAW

\begin{tabular}{|c|c|c|c|c|}
\hline Date & About & Establisher & Note & $\begin{array}{l}\text { Halal } \\
\text { Thayyib/ } \\
\text { Kosher }\end{array}$ \\
\hline 1641 & Food adulteration law; meat and pork protection & $\begin{array}{l}\text { The Massachusetts } \\
\text { Bay Colony }\end{array}$ & & $\begin{array}{l}\text { Thayyib } \\
\text { Kosher }\end{array}$ \\
\hline 1646 & Colonial Assize of Bread & & & $\begin{array}{l}\text { Thayyib } \\
\text { Kosher }\end{array}$ \\
\hline 1880 & $\begin{array}{l}\text { Recommendation of national food and drug law's } \\
\text { enactment }\end{array}$ & & $\begin{array}{l}\text { Recommended by the chief chemist of the U.S Department } \\
\text { of Agriculture (USDA) but it was reluctant to comply by } \\
\text { Congress }\end{array}$ & $\begin{array}{l}\text { Thayyib } \\
\text { Kosher }\end{array}$ \\
\hline $\begin{array}{l}\text { Decem } \\
\text { ber } 5 \text {, } \\
1905\end{array}$ & $\begin{array}{l}\text { Interstate commerce of adulterated and } \\
\text { misbranded foods, drinks, and drugs law }\end{array}$ & $\begin{array}{l}\text { President Theodore } \\
\text { Roosevelt }\end{array}$ & $\begin{array}{l}\text { To response public awareness and findings of Poison } \\
\text { Squad Study }\end{array}$ & $\begin{array}{l}\text { Thayyib } \\
\text { Kosher }\end{array}$ \\
\hline $\begin{array}{l}\text { June } \\
30 \\
1906\end{array}$ & Pure Food and Drug Act & $\begin{array}{l}\text { Senators and } \\
\text { representatives }\end{array}$ & $\begin{array}{l}\text { These provisions regulate the prohibition of the } \\
\text { development of misbranded and adulteration of food, } \\
\text { drinks, and drugs in interstate commerce. }\end{array}$ & $\begin{array}{l}\text { Thayyib } \\
\text { Kosher }\end{array}$ \\
\hline $\begin{array}{c}\text { June } \\
30 \\
1906 \\
\end{array}$ & Pure Food and Drug Act & $\begin{array}{c}\text { Senators and } \\
\text { representatives }\end{array}$ & $\begin{array}{l}\text { These provisions regulate the prohibition of the } \\
\text { development of misbranded and adulteration of food, } \\
\text { drinks, and drugs in interstate commerce. }\end{array}$ & $\begin{array}{l}\text { Thayyib } \\
\text { Kosher }\end{array}$ \\
\hline $\begin{array}{c}\text { June } \\
30 \\
1906\end{array}$ & Federal Meat Inspection Act & President Roosevelt & $\begin{array}{l}\text { Administrated by the Bureau of Animal Industry housed in } \\
\text { USDA }\end{array}$ & $\begin{array}{l}\text { Thayyib } \\
\text { Kosher }\end{array}$ \\
\hline
\end{tabular}




\begin{tabular}{|c|c|c|c|c|}
\hline 1938 & $\begin{array}{l}\text { Federal Food, Drug, and Cosmetic Act (FDCA). } \\
\text { New Provisions: } \\
\text { a. Providing those safe tolerances be set for } \\
\text { unavoidable poisonous substances } \\
\text { b. Authorizing the standards for identity, quality, } \\
\text { and fill-of-container of foods. } \\
\text { c. Authorizing factory inspection. } \\
\text { d. Adding the remedy of court injunctions to the } \\
\text { previous penalties of seizures and prosecutions, } \\
\text { and } \\
\text { e. Expanding the definitions of adulteration and } \\
\text { misbranding }\end{array}$ & Congress & $\begin{array}{l}\text { Increasing public concerns related to food security, and } \\
\text { inability to meet and run USDA food and drug regulation } \\
\text { under the } 1906 \text { law and related cases sulfonamides terrible } \\
\text { case. }\end{array}$ & $\begin{array}{l}\text { Halal } \\
\text { Thayyib } \\
\text { Kosher }\end{array}$ \\
\hline 1951 & $\begin{array}{l}\text { Examining the safety of food additives and } \\
\text { pesticides }\end{array}$ & $\begin{array}{l}\text { House Committee } \\
\text { under the direction of } \\
\text { Chairman James } \\
\text { Delaney }\end{array}$ & & $\begin{array}{l}\text { Thayyib } \\
\text { Kosher }\end{array}$ \\
\hline 1954 & Pesticide Amendment & Congress & Amendment of 1938 FDCA & $\begin{array}{l}\text { Thayyib } \\
\text { Kosher }\end{array}$ \\
\hline 1957 & $\begin{array}{l}\text { Poultry Products Inspection Act (as amended } \\
\text { 1968) }\end{array}$ & & Like that of the Meat Inspection Act. & $\begin{array}{l}\text { Thayyib } \\
\text { Kosher }\end{array}$ \\
\hline 1958 & Food Additive Amendment & Congress & $\begin{array}{l}\text { Amendment of } 1938 \text { FDCA. One important provision of } \\
\text { this amendment is called the Delaney Clause that prohibits } \\
\text { the addition of any food that causes cancer. }\end{array}$ & $\begin{array}{l}\text { Thayyib } \\
\text { Kosher }\end{array}$ \\
\hline 1960 & Color Additive Amendment & Congress & $\begin{array}{l}\text { Amendment of } 1938 \text { FDCA. It requires manufacturers to } \\
\text { establish the safety of color additives in food, drugs, and } \\
\text { cosmetics. }\end{array}$ & $\begin{array}{l}\text { Thayyib } \\
\text { Kosher }\end{array}$ \\
\hline 1966 & Fair Packaging and Labelling Act & & $\begin{array}{l}\text { It's requiring truthful and informative labeling of packages } \\
\text { that are sold through interstate commerce. }\end{array}$ & Thayyib \\
\hline 1970 & The Egg Product Inspection Act & & Giving an authority to USDA for regulating eggs products & $\begin{array}{l}\text { Halal } \\
\text { Thayyib }\end{array}$ \\
\hline 1970 & $\begin{array}{l}\text { Establishment of a new national agency, which is } \\
\text { Environmental Protection Agency (EPA) based } \\
\text { on book of Silent Spring that described about the } \\
\text { dangerous of pesticides' effect to the } \\
\text { environment. }\end{array}$ & $\begin{array}{l}\text { Federal agency. To do } \\
\text { some works such as } \\
\text { research, monitoring, } \\
\text { standard-setting, and } \\
\text { enforcement activities } \\
\text { to ensure the } \\
\text { environment is } \\
\text { protected. }\end{array}$ & $\begin{array}{l}\text { Its responsibilities are to protect human health and to } \\
\text { safeguard the natural environment-air, water, and land. }\end{array}$ & $\begin{array}{l}\text { Thayyib } \\
\text { Kosher }\end{array}$ \\
\hline 1990 & Nutrition labeling and Education Act & $\begin{array}{l}\text { Amendment of } 1938 \\
\text { FDCA }\end{array}$ & $\begin{array}{l}\text { It's requiring specific nutrition information to appear on } \\
\text { food labels }\end{array}$ & $\begin{array}{l}\text { Halal } \\
\text { Thayyib }\end{array}$ \\
\hline 1994 & Dietary Supplement Health and Education Act & & $\begin{array}{l}\text { This Act describes about: } \\
\text { a. Dietary supplements and dietary ingredients and } \\
\text { classified them as food. } \\
\text { b. Establishing a commission to recommend how to } \\
\text { regulate claims }\end{array}$ & $\begin{array}{l}\text { Halal } \\
\text { Thayyib } \\
\text { Kosher }\end{array}$ \\
\hline 1996 & Saccharin Notice Repeal Act & & Repealing the saccharin notice requirements. & Thayyib \\
\hline 1996 & Food Quality Protection Act & $\begin{array}{l}\text { Amended the FDCA, } \\
\text { eliminating } \\
\text { application of the } \\
\text { Delaney proviso to } \\
\text { pesticides. }\end{array}$ & & Thayyib \\
\hline 2002 & The Bioterrorism Act & Congress & $\begin{array}{l}\text { The public health security and Bioterrorism Preparedness } \\
\text { and Response Act of } 2002 \text { (the Bioterrorism Act). The Act } \\
\text { is divided into five parts: } \\
\text { 1. Introduction } \\
\text { 2. Title I- National Preparedness for Bioterrorism and } \\
\text { Other Public Health Emergencies } \\
\text { 3. Tittle II- Enhancing Controls on Dangerous Biological } \\
\text { Agents and Toxins } \\
\text { 4. Title III-Protecting Safety and Security of Food and } \\
\text { Drug Supply. } \\
\text { 5. Title IV-Drinking Water Security and Safety. } \\
\text { 6. Title V-Additional Provision. }\end{array}$ & Thayyib \\
\hline
\end{tabular}

\section{B. Indonesian Food Laws}

1) The Act of 18/2012 on Food
The definition of food -based on article 1 number 1 of Act of 18/2012 on Food (Food Laws)- is everything that comes from biological sources of agricultural products, plantations, forestry, fisheries, livestock, water, and water 
both processed and not processed. Which intend as food or drinks for consumption human beings, including food additives, food raw materials, and other materials used in the process of preparing, processing, and/or making food or beverages.

In Article 2 of the food laws, it explains that the implementation of food based on theprinciples of sovereignty, independence, resilience, security, benefits, equity, sustainability, and justice [18]. Linkages relevant principles contained in the Halal Thayyib food safety principles, namely food safety. According to Article 67 up to 69 , food security organized to keep food safe, sanitary, high quality, nutritious, and does not conflict with religion, faith and culture. Food safety is intended to prevent the possibility of biological, chemical and other contaminants that can interfere, harm and endanger human health. Therefore, the government and regional governments guarantee the realization of the implementation of food security in each food chain in an integrated manner.

Regarding the guarantee of Halal products, for those required, in general, regulated in article 95 of the Food Act, namely the government and localgovernments have to supervise the implementation of Halal product guarantee systems for those required for food, and the application of the system under the provisions of the legislation. Namely, the Government Regulation of the Republic of Indonesia No. 28/2004 on Food Safety, Quality, and Nutrition as well as the Act No. 33/2014 on Halal Products Guarantees.

2) Indonesian Government Regulation No. 17/2015 on Food Security and Nutrition [19]

This Government Regulation is prepared based on consideration for implementing the provisions of Article 28 paragraph (4), Article 43, Article 45 paragraph (3), Article 48 paragraph (2), Article 52 paragraph (2), Article 54 paragraph (3), Article 112, Article 116, and Article 131 paragraph (2) of the Act No. 18/2012 on Food needs to stipulate an Indonesian Government Regulation on Food Security and Nutrition (PeraturanPemerintahtentangKetahananPangandanGi $z i / \mathrm{PPKPG})$. PPKPG consists of 10 Chapters and 90 Articles.

TABLE II.

PPKPG CONTENT.

\begin{tabular}{|l|l|l|}
\hline Chapter & \multicolumn{1}{|c|}{ Talk About } & \multicolumn{1}{c|}{ Article } \\
\hline I & General Provisions & $1 \& 2$ \\
\hline II & $\begin{array}{l}\text { Government and Regional } \\
\text { Government Reserves }\end{array}$ & $3-24$ \\
\hline III & $\begin{array}{l}\text { Diversification of Food and } \\
\text { Nutrition Improvement Society }\end{array}$ & $25-40$ \\
\hline IV & $\begin{array}{l}\text { Food Crisis Preparedness and Food } \\
\text { Crisis Mitigation }\end{array}$ & $41-58$ \\
\hline V & $\begin{array}{l}\text { Food Distribution, Food Trade, Food } \\
\text { Aid }\end{array}$ & $59-70$ \\
\hline VI & Supervision & $71-74$ \\
\hline VII & $\begin{array}{l}\text { Food and Nutrition Information } \\
\text { System }\end{array}$ & $75-85$ \\
\hline VIII & Community Engagement & $86-87$ \\
\hline IX & Transitional Provisions & 88 \\
\hline
\end{tabular}

\begin{tabular}{|l|l|c|}
\hline Chapter & \multicolumn{1}{|c|}{ Talk About } & Article \\
\hline $\mathrm{X}$ & Final provisions & $89-90$ \\
\hline
\end{tabular}

3) The Act No. 33/2014 on Halal Product Certification [20]

This legislation was formed using the consideration that the 1945 Constitution of the Republic of Indonesia mandated the state to guarantee the independence of each citizen to embrace their respective religions and to worship according to their faith and belief. Whereas to ensure that every religion adherent to worship and carry out his religious teachings, the state is obliged to provide protection and guarantees about the Halal of products consumed and used by the community. Whereas all Halal products circulating in the neighborhood are not guaranteed; that the Halal arrangement of a product at this time has not guaranteed legal certainty and needs to be regulated, in laws' perception. So, based on these considerations, the Act on Halal Products Guarantee is required. The Act was passed in Jakarta on October $17^{\text {th }}$ 2014, by President Dr. H. SusiloBambangYudhoyono and promulgated in Jakarta on the same date.

TABLE III

HPC CONTENT

\begin{tabular}{|l|l|l|}
\hline $\begin{array}{c}\text { Cha } \\
\text { pter }\end{array}$ & \multicolumn{1}{|c|}{ Talk About } & \multicolumn{1}{|c|}{ Article } \\
\hline I & General Provision & $1-4$ \\
\hline II & The Insurers Halal Products & $5-16$ \\
\hline III & Materials and Process Halal Product & $17-22$ \\
\hline IV & Business & $23-28$ \\
\hline V & $\begin{array}{l}\text { Procedure of Obtaining A Certificate of } \\
\text { Halal }\end{array}$ & $29-45$ \\
\hline VI & International Cooperation & $46-48$ \\
\hline VII & Supervision & $49-52$ \\
\hline VIII & Community Participation & $53-55$ \\
\hline IX & Penalty Provision & $56-57$ \\
\hline X & Transitional Transition & $58-63$ \\
\hline XI & Closing & $64-68$ \\
\hline
\end{tabular}

4) Identifying the overlapping spaces on both definitions, laws and, regulations

Legislation related to food in Indonesia and America is very diverse. A bit of analysis associated with the existing laws can identify that:

a. Halal Thayyib in Indonesia is set in legislationfor food, although not explicitly said Thayyib etched, but the setting of the terms Thayyib is set. On the other hand, the rule of Kosher in American laws is protected by the government by instituting Kosher certification for those who are subject to Kosher food laws. The laws and regulations in America are also following Kosher rules in general. Halal Thayyib in Indonesia by using the basic principles of Islamic teachings, in practice sometimes it has not been well implemented, due to variousfactors, ranging from understanding, supervision to law 
enforcement. In America, Halal certification is not protected in public law, and it is considered as private law. b. The definition of food in America is containedin the Act that regulates Food, Drug, and Cosmetic. Meanwhile, in Indonesia, there are no rules about Drug and Cosmetic in the food's Act. This condition has an impact on the definition that appears, then institutionalized in the legislation in each country in a legal basis. Based on Indonesian food laws [18], food is something derived from biological sources of agricultural products, plantations, forestry, fisheries, livestock, water, and water, both processed and unprocessed which are intended as food or drinks for human consumption, including food additives, food raw materials, and other materials used in the preparation, processing, and / or manufacture of food.

c. Likewise, the definition of Halal in Indonesian regulations has been defined in the special general legislation for all Indonesian people which refers to the Halal Thayyib food laws, in the Act on Halal Product Certification. Then, in America, the definition of Kosher is published in the rules set out in the Kosher Food Labeling Act [21], which respects beliefs and religion to implement food laws according to the provisions of faith and religion.

\section{EXAMINING THE ONTOLOGICAL GAP}

Halal Thayyib is a unison. The ontology vacuum that can be explored is that in Indonesia there is a regulation about Halal, but the principle related to Thayyib explicitly in food regulations does not yet exist. While it is clear that it states in Article 59 (b) of Act No. 18/2012, the government and local government is obliged to increase compliance with the quantity and quality of food consumption by providing a variety of foods, nutritionally balanced, safe, and does not conflict with religion, faith and culture. Here, the concept Thayyib has seen in literature in Islamic food laws as integral and inseparable, but it has not been absorbed in Indonesia's regulation of food contextually. Concerning Kosher, there is no Kosher study in Indonesia.

In America, the study of food laws based on the application of the belief rules that have been publicly recognized is Kosher food laws based on the principle of Jewish food principles. The legal food gap occurs when the entire state has not legally protected the food laws in Halal Thayyib, and its protection is still a private law. This condition shows that the application of human rights in carrying out beliefs has not been fully protected by the state.

\section{CONCLUSION}

Based on the above explanation, it can be concluded that:

1) Halal food laws in Indonesia adapts from Islamic food laws principles. This situation under Article 1 paragraph 2 of Act No. 33/2004 on Halal Product Guarantee. Namely, Halal products are products that have been declared lawful following Islamic teachings. And this law applies throughout Indonesia to people who are subject to the Halal Thayyib food laws. Kosher defines the food laws based on Jews teachings.

2) Comparison of written laws and regulations that have been instituted in both countries vis-à-vis Halal and Kosher foods are varies. Firstly, the rules on foods in both countries have a different perception. In Indonesia, food describes as food in unison, but in the Act, the terms of Drugs and Cosmetics are excluded, whereas that it is included on the Americans food laws. Secondly, the Indonesian food laws, especially in Halal Thayyib terms, is binding all community through government and local government surveillance. In contrary, the Kosher Act is based on the bill of the states. In addition, everything that Kosher must be Halal Thayyib.

3) The ontological gaps appear in Halal Thayyib and Kosher its self. On Halal Thayyib terms, Indonesian food laws have not stated the names of Thayyib explicitly in the Act, even though the substance it has already existed. This situation affects the social understanding, especially indepth knowledge about Halal.

\section{REFERENCES}

[1] V. N. Mathew, A. M. R. binti A. Abdullah, and S. N. binti M. Ismail, "Acceptance onHalal Food among Non-MuslimConsumers," Procedia - Soc. Behav. Sci., vol. 121, pp. 262-271, 2014.

[2] J. Neal D. Fortin, Food Regulation; Law, Science, Policy and Practice. New Jersey: Wiey, 2009.

[3] S. Y. Al-Qaradawi, The Lawful and The Prohibited in Islam. Egypt, 2007.

[4] S. Mansor, M. Z. Razaly, and M. I. Ismail,"Halalan Toyyiban Concept in Retailing management: A Conceptual Paper," inMalaysia Indonesia International Conference on Economics, Management and Accounting (MIICEMA 2014), 2014, no. August, pp. 229-242.

[5] P. S. TQN, "Persentase Jumlah Umat Islam Berbagai Daerah di Indonesia," Sang Pencerah: Muhammadiyah Post, 2014. [Online]. Available: http://sangpencerah.id/2014/12/persentase-jumlah-umatislam-berbagai/. [Accessed:31-Jul-2018].FAO, "Food security," Policy Br., no. 2, pp. 1-4, 2006

[6] FAO, Trade and Food Standards. The Food and Agriculture Organization of the United Nations and the World Trade Organization, 2017.

[7] M. H. Zulfakar, M. M. Anuar, and M. S. A.Talib, "Conceptual Framework on HalalFood Supply Chain IntegrityEnhancement," Procedia - Soc. Behav. Sci., vol. 121, pp. 58-67, 2014.

[8] S. Arif and S. Sidek, "Application ofHalalan Tayyiban in The Standard Reference for Determining Malaysian Halal Food," Asian Soc. Sci., vol. 11, no. 17, pp. 116-129, 2015.

[9] S. Zailani, K. Kanapathy, M. Iranmanesh, and M. Tieman, "Drivers of HalalOrientation Strategy Among Halal Food Firms," Br. Food J., vol. 117, no. 8, pp. 2143-2160, 2015.

[10] Norizah Mohamad and C. Backhouse, "AFramework for the Development of HalalFood Products in Malaysia," Int. Conf. Ind. Eng. Oper. Manag., pp. 693-702, 2014.

[11] A. . Mohamad, A. . Baharuddin, and A.Ryskam, "Halal Industry in Singapore: A Case Study of Nutraceutical Products,"Sains Humanika, vol. 4, no. 2, pp. 35-40, 2015. 
[12] I. N. A. Rahman, R. Saleh, S. A. Rahman, and D. Hashim, "A Review on Factors ofNon-Compliance of Halal Standards Among Restaurant Operators in KualaLumpur," International Business Management, vol. 6, no. 6. pp. 611-620, 2012.

[13] Z. Zakaria, "Tapping Into the World HalalMarket: Some Discussions on MalaysianLaws and Standards," Shariah J., vol. 16, pp. 603-616, 2008.

[14] Patricia A. Curtis, Guide to Food Laws and Regulations, First. Iowa, USA: Blackwell Publishing, 2005.

[15] R. Jennifer and T. Johanna, "Kosher andHalal_Religious Observance AffectingDietary Intakes.Pdf," 2002.

[16] M. Webster, “adulterate adjective,"Merriam-Webster, 2018. [Online]. Available: $\quad$ https://www.merriamwebster.com/dictionary/adulterate.Indonesia, Act 18/2012 of Food Law.Indonesia: Republic Indonesia's Ministry of Law and Human Rights, 2012, pp. 1-41.

[17] "Indonesian Government Regulation No. 17/2015," 2015. Indonesia, Act of Halal Product Guarantee No. 33/2014. 2014, pp. 1-27.ACLU, "Georgia Governor Signs NewLaw Ensuring Equality In Kosher FoodLabeling American Civil LibertiesUnion," ACLU, 2010. [Online]. Available:https://www.aclu.org/news/georgia-governorsigns-new-law-ensuring-equality-kosher-food-labeling. [Accessed: 19-Oct-2018]. 